\title{
Implementation Of Criminal Enforcement In The Circulation Of VCD (Video Compact Disc) On The Level Of Investigations In Rembang Polres
}

\section{Area}

\author{
Priyantono $^{1}$ and Jawade Hafidz ${ }^{2}$
}

Abstract. This study aims to determine and analyze the implementation of criminal law enforcement in pirated VCD (Video Compact Disc) cases at the investigation level in the Rembang Police area, obstacles and efforts to overcome them.

The method used is sociological juridical, descriptive analytical research specifications. The data used are primary data and secondary data. Data collection methods are field studies and library studies. The method of data analysis uses qualitative analysis. As a knife of analysis, law enforcement theory is used, and law effectiveness theory is used.

The results showed that the implementation of criminal law enforcement in the case of pirated VCD (Video Compact Disc) at the level of investigation in the Rembang Police District area was in accordance with the provisions of the applicable laws and regulations, namely through several stages namely investigation, forced effort, examination, determination of suspects, filing, submitting case files to the public prosecutor and submitting the suspect and evidence to the public prosecutor. Obstacles in the implementation of criminal law enforcement in pirated VCD (Video Compact Disc) cases at the investigation level in the Rembang Police Precinct are investigators who have difficulty tracking down perpetrators, difficulties in bringing in expert witnesses, lack of legal awareness from perpetrators or from the public.

Keywords: Criminal Law Enforcement; Investigation; Distribution Of Pirated Video Compact Discs.

\section{Introduction}

Pirated VCD (Video Compact Disc) crime prevention efforts undertaken by the police so far have not been able to eradicate crimes that have occurred, but can be rewarded because Police actions can show a decrease in pirated VCD (Video Compact Disc) crime rates. On the other hand, people's economic behavior and conditions that do not respect the rights of other people's work and cheaper offers make pirated VCD (Video Compact Disc) circulation in society fertile.

Circulation of pirated VCD (Video Compact Disc) with adverse effects caused, is not only experienced by the creator but also the state is the duty of the Police to always be always active in overcoming it. Thus, the role of the police is needed to work extra by cracking down on pirated VCD dealers (Video Compact Disc) to provide a deterrent effect, so that security and public order can always be maintained.

Rembang Regency as one of the regions in Central Java Province, with all its potential, has become one of the developed and increasing regions in its economic sector.

\footnotetext{
1 Student of Master of Law, Sultan Agung Islamic University (UNISSULA), Semarang, email antonlee897@gmail.com

${ }^{2}$ Lecturer of Faculty of Law, Sultan Agung Islamic University (UNISSULA), Semarang
} 
However, one of the things that becomes an obstacle in creating law order in the Rembang area is the low awareness of the community to comply with all legal rules.

To create a society that is aware of the law and creates territorial conduct, requires an effort to deal seriously with law enforcement to create security and order in the community. In addition, community participation is also very important, bearing in mind that legal development cannot work well if the community and law enforcement do not co-exist.

This is where the task of the police which aims to protect the community is tested. The police will always try to carry out their duties in accordance with the provisions stipulated in the law. Community cooperation is needed so that the task of the Police as a community partner can go hand in hand and is balanced.

From the description of the background of the problem above, the authors conducted a study to find out more about: "Implementation of Criminal Law Enforcement in Circulation of VCD (Video Compact Disc) Cases Piracy in Investigations in the Rembang Police Area"

Based on the background description described above, the following problems are formulated: How is the implementation of criminal law enforcement in the case of pirated VCD (Video Compact Disc) at the level of investigation in the area of Rembang Police?; What are the obstacles in the implementation of criminal law enforcement in the case of pirated VCD (Video Compact Disc) at the level of investigation in the Rembang Police District area?; How is the effort to overcome obstacles in criminal law enforcement in the case of pirated VCD (Video Compact Disc) at the level of investigation in the Rembang Police area?

\section{Research Methods}

The method of approach used in this research is the method of sociological juridical approach, which is in addition to using the principles and legal principles in reviewing, viewing, and analyzing problems, this study also reviews how they are implemented in practice. ${ }^{3}$ The research specification is analytical descriptive, which provides a clear, detailed and systematic picture. The data used include primary data and secondary data obtained through field studies and literature studies. The data analysis method uses qualitative analysis.

\section{Results and Discussion}

\subsection{Implementation of Criminal Law Enforcement in the Pirated of VCD (Video Compact Disc) Case at the Investigation Level in the Rembang Police Area}

Crimes against copyrights in Act No. 28 of 2014 concerning Copyright are placed as crimes against property or crimes against assets. This is because the object of copyright can be copyright as immaterial property rights. Copyright holders can transfer all or part of the copyright to others through inheritance, grants or wills or in other legal ways. These rights are given legal protection by the Copyright Act. One

${ }^{3}$ Ronny Hanitijo Soemitro, 1990, Metodologi Penelitian Hukum dan Jurimetri, Jakarta: Ghalia Indonesia, p. 33. 
form of legal protection is the provision of criminal sanctions against people who violate copyrights by way of violating the law. ${ }^{4}$

Based on interviews with IPDA Pujiono, data were obtained that there were three cases of copyright infringement in the form of pirated VCD (Video Compact Disc) which had been handled by the Rembang Police. However, of the three cases only one case was proceeded to the investigation stage, while the other two cases were only carried out coaching actions. ${ }^{5}$

According to Ipda Pujiono, the National Police did not directly process the pirated VCD dealer (Video Compact Disc) in the community. In upholding the law, the Polri does not only stand on a juridical basis, but also considers various factors such as economic factors. Polri sees from the side of the perpetrators why committing Copyright violations such as distributing pirated VCD (Video Compact Disc). Facts in the community show that the perpetrators circulated pirated VCD (Video Compact Disc) to fulfill their daily needs. This is because the principals generally come from economically weak groups. If the police enforce criminal law in accordance with the provisions of the law, it will cause problems for the family of the offender, considering the offender is the backbone of the family who provides for his wife and children. ${ }^{6}$

Before there was a change in the Copyright law, Act No. 28/2014, violations against copyright were ordinary offenses, so that without having to wait for complaints from the injured party, law enforcement authorities were authorized to act against copyright infringement. However, after the enactment of Act No. 28 Of 2014, then copyright infringement is a complaint offense. For this reason, since the law came into force, the police cannot take action against the circulation of pirated VCD (Video Compact Disc) without complaints from those who feel disadvantaged. This is the reason that criminal law enforcement in the field of copyright is the last resort taken after dispute resolution efforts have not been resolved.

Criminal law enforcement in the case of pirated VCD (Video Compact Disc) in Rembang Police that occurred was prior to the enactment of Act No. 28 of 2014, so that the legal basis used was Act No. 19 of 2002. Enforcement of criminal law is carried out through a series of activities investigations based on the Criminal Procedure Code. In addition, related to the investigation of copyright infringement, it is specifically regulated in Article 71 (2) of Act No. 19 of 2002.

Criminal law enforcement in the case of pirated VCD (Video Compact Disc) in the Rembang Police through investigative activities is in accordance with applicable laws and regulations. Based on the provisions of Article 10 paragraph (1) Perkap Polri Number 16 of 2019 regarding Criminal Investigations, it is stated that criminal activity investigation consists of investigation, commencement of investigation, forced effort, examination, determination of suspects, filing, submission of case files, surrender of suspects and goods evidence, and termination of investigation. The forced effort

\footnotetext{
${ }^{4}$ Devega R. Kilanta, Law Enforcement of Copyright Based on Law Number 28 Of 2014 Regarding Copyright, Lex Crimen, Vol.IV / No. 3 / May / 2017, p.93.

${ }^{5}$ Results of an interview with IPDA Pujiono, Investigator of the Rembang District Police, on March 5, 2020.

${ }^{6}$ Results of an interview with IPDA Pujiono, Investigator of the Rembang District Police, on March 5, 2020.
} 
referred to in Article 10 paragraph (1) Perkap Polri Number 16 of 2019 includes summons, arrests, detention, search, seizure and examination of letters

Investigators carried out investigative acts after reports of pirated VCD (Video Compact Disc) crime. After receiving the report, officers went to the crime scene to conduct an investigation. Based on the results of the investigation, there was evidence that a pirated VCD (Video Compact Disc) crime had been committed, so the report was proceeded to the investigation stage.

In the case example there was no forced effort in the form of an arrest because the perpetrators along with the evidence were immediately secured by Pamotan Police Station officers and then handed over to the Rembang Police Precinct. In that case also no detention was taken against the suspect. The next stage is confiscation of the evidence which is carried out on the basis of a seizure warrant and the minutes of confiscation have been made. Confiscation of evidence has also been approved by the Rembang District Court.

To prove the fulfillment of pirated VCD (Video Compact Disc) criminal offenses, an examination of witnesses, expert witnesses and examination of the suspect is carried out. Each inspection is made a separate official report which is initialed by the examiner. This is in accordance with the provisions of Article 23 Perkap Polri Number 16 Of 2019 concerning Criminal Investigations.

After all actions from the crime scene to the examination of the suspect are complete, the investigator will complete the case file. The completion of the case file is based on Article 27 Perkap Polri Number 16 of 2019, namely by making a resume as an overview and conclusion of the results of criminal investigations, after completion of the investigation the investigator must compile a case file which includes the administrative completeness of the investigation.

Before it is submitted to the public prosecutor, the case file is first submitted to the supervisor of the investigator for research. After the files are complete and fulfilling the requirements, binding and sealing are immediately carried out and then submitted to the public prosecutor.

Based on the provisions of Article 28 Perkap Polri Number 16 Of 2019 regarding Criminal Investigations, the case file submission to the Public Prosecutor is carried out after the filing in the investigation process is finished. In this case it is possible that the file was returned by the public prosecutor to the investigator due to lack of case content. In this case the investigator must complete the file in accordance with the instructions given by the public prosecutor and then return it to the public prosecutor. After the case file is declared complete by the public prosecutor, the next step is the surrender of the suspect and evidence. This is stipulated in Article 29 of Perkap Polri Number 16 of 2019 concerning Criminal Investigations. With the submission of case files, suspects and evidence to the public prosecutor, the investigation process has been completed.

Criminal law enforcement in pirated VCD (Video Compact Disc) cases that occur in the Rembang Police jurisdiction is in accordance with the theory of law enforcement as stated by Sudikno Mertokusumo which states that in enforcing the law there are three elements that must be considered, namely legal certainty, benefits and justice .

${ }^{7}$ Sudikno Mertokusumo, 1999, Mengenal Hukum, Suatu Pengantar, Yogyakarta: Liberty, p.145. 
Judging by the theory of legal effectiveness, criminal law enforcement in the case of pirated VCD (Video Compact Disc) during the investigation stage in the Rembang Police area is not yet effective. According to Raida L Tobing, in a country based on law, an effective law can be applied if it is supported by three pillars, namely an authoritative institution or law enforcement that can be relied upon, clear systematic legal regulations and high public legal awareness. ${ }^{8}$

\subsection{Obstacles in the Implementation of Criminal Law Enforcement in Pirated VCD Circulation (Video Compact Disc) Cases at the Investigation Level in the Rembang Police Area}

Criminal law enforcement in pirated VCD (Video Compact Disc) cases at the level of investigation in the Rembang Police area does not always run smoothly. There are several obstacles in its implementation, namely: ${ }^{9}$

- Law enforcement officials have difficulty tracking the perpetrators

Many pirated VCD dealers (Video Compact Disc) in the Rembang Police Area, but law enforcement officers have difficulty eradicating pirated VCD dealers (Video Compact Disc) because pirates play cat and mouse. In the event that there is a raid from the police, the perpetrators stop distributing pirated VCD (Compact Disc Video), and if there are no raids from the police then the offender re-opens the stalls and circulates pirated VCD (Video Compact Disc) again.

- Investigators find it difficult to bring in expert witnesses

Investigations of pirated VCD (Video Compact Disc) cases must use expert witnesses, to prove the truth that the circulated VCD (Video Compact Disc) is a pirated product. The procedure to bring in expert witnesses is constrained by complicated bureaucracy and a long time. In this case the investigator must send a letter of request to the Ministry of Justice and Human Rights, only after that the Ministry of Justice and Human Rights will appoint an expert witness. The complexity of the procedure for the application of an expert witness resulted in the length of the expert witness being present in providing the information needed.

- Lack of legal awareness from the perpetrators

Pirated VCD dealers (Video Compact Disc) have low legal awareness. In this case, the dealer seems to underestimate the rule of law and repeatedly circulate pirated VCD (Video Compact Disc) on the market. This is because the economic motive as a livelihood to meet the needs of daily life, so there is a feeling to repeat his actions in the future even though there has been a warning from the police when conducting raids.

- Lack of legal awareness from the public

The public in general has a tendency to buy cheap VCD (Video Compact Disc) regardless of whether the product is original or pirated. This affects the amount of pirated VCD (Video Compact Disc) circulation on the market, because the public

\footnotetext{
${ }^{8}$ Raida L Tobing, et al, 2011, Efektivitas Undang-Undang Monrey Loundering, Jakarta: National Law Development Agency, Indonesian Ministry of Law and Human Rights, p. 11.

${ }^{9}$ Results of an interview with IPDA Pujiono, Investigator of the Rembang District Police, on March 5, 2020.
} 
interest in pirated VCD (Video Compact Disc) is very high. The tendency of people to buy pirated VCD (Video Compact Disc) is due to lack of legal awareness in the community. Ordinary people generally do not know that pirated VCD (Video Compact Disc) are illegal goods and violate the law.

\subsection{Efforts to Overcome Obstacles in Criminal Law Enforcement in Pirated VCD Circulation (Video Compact Disc) Cases at the Investigation Level in the Rembang Police Area}

Efforts to overcome obstacles in criminal law enforcement in pirated VCD (Video Compact Disc) cases at the investigation level at the Rembang Police Station are as follows: ${ }^{10}$

- Law enforcement officials coordinate with APPRI

The efforts of law enforcement officers in tracing pirated VCD dealers (Video Compact Disc) are by coordinating with related parties namely APPRI. APPRI then traced the field to market shelters until finally the pirated VCD dealer (Video Compact Disc) could be secured.

- Investigators coordinate with the Ministry of Law and Human Rights and await the arrival of designated expert witnesses.

Efforts by investigators to be able to present expert witnesses for questioning related to pirated VCD (Video Compact Disc) cases, are coordinating with the Ministry of Law and Human Rights. In the case of an old expert witness, the investigator must wait until the expert witness is ready to provide information.

- Guidance on pirated VCD dealers (Video Compact Disc)

In an effort to overcome the lack of legal awareness of pirated VCD dealers (Video Compact Disc), law enforcement officers provide guidance to pirated VCD (Video Compact Disc) sellers in both market stalls and street vendors. In this case the police gave a message to the sellers not to sell pirated VCD (Video Compact Disc) and the legal consequences if they continued to sell pirated VCD (Video Compact Disc).

- Coordinate with the Ministry of Law and Human Rights

Lack of legal awareness from the public about copyright due to ignorance from ordinary people that buying pirated products is the same as helping dealers of pirated VCD (Video Compact Disc). For this reason, the police coordinated with the Ministry of Law and Human Rights so that the public be socialized to participate in preventing pirated VCD (Video Compact Disc) distribution by not buying pirated VCD (Video Compact Disc) products.

\section{Closing}

\subsection{Conclusion}

- The implementation of criminal law enforcement in the case of pirated VCD (Video Compact Disc) at the level of investigation in the area of Rembang Police has been

\footnotetext{
${ }^{10}$ Results of an interview with IPDA Pujiono, Investigator of the Rembang District Police, on March 5, 2020.
} 
in accordance with the provisions of the applicable laws and regulations namely KUHAP, Act No. 28 Of 2014 concerning Copyright and Perkap Polri Number 16 Of 2019 concerning Criminal Investigations. Investigations go through several stages, namely investigation, forced efforts, examination, determination of suspects, filing, submission of case files to the public prosecutor as well as the surrender of suspects and evidence to the public prosecutor.

- Obstacles in the implementation of criminal law enforcement in pirated VCD (Video Compact Disc) cases at the investigation level in the Rembang Police Precinct are investigators who have difficulty tracking down perpetrators, difficulties in bringing in expert witnesses, lack of legal awareness from perpetrators or from the public.

- Efforts to overcome obstacles in criminal law enforcement in the case of pirated VCD (Video Compact Disc) at the level of investigation in the Rembang Police area are to coordinate with related parties such as APPRI or the Ministry of Law and Human Rights, awaiting the readiness of expert witnesses to provide information, make efforts guidance for pirated VCD dealers (Video Compact Disc) and coordination with the most effective ministries so that public outreach is carried out.

\subsection{Suggestion}

- For the government, especially the Ministry of Law and Human Rights should provide legal socialization to the public related to copyright infringement.

- For law enforcement officers should be able to be professional so that not only dealers are dealt with but also manufacturers of pirated VCD (Video Compact Disc)

- For the community, they should actively participate in preventing the circulation of pirated VCD (Video Compact Disc) by not buying original VCD (Video Compact Disc) products.

\section{References}

\section{Book}

[1] Ronny Hanitijo Soemitro, 1990, Metodologi Penelitian Hukum dan Jurimetri, Jakarta: Ghalia Indonesia

[2] Sudikno Mertokusumo, 1999, Mengenal Hukum, Suatu Pengantar, Yogyakarta: Liberty

\section{Regulations}

[1] The 1945 Constitution of the Republic of Indonesia.

[2] Act No. 8 of 1981 concerning the Criminal Procedure Code.

[3] Act No. 2 of 2002 concerning the Indonesian National Police.

[4] Act No. 28 of 2014 concerning Copyright.

[5] Republic of Indonesia Police Chief Regulation Number 16 Of 2019 regarding Criminal Investigations. 


\section{Journals}

[1] Devega R. Kilanta, Law Enforcement of Copyright Based on Act No. 28 Of 2014 Regarding Copyright, Lex Crimen, Vol.IV / No. 3 / May / 2017.

[2] Raida L Tobing, et al, 2011, Efektivitas Undang-Undang Monrey Loundering, Jakarta: National Law Development Agency, Indonesian Ministry of Law and Human Rights 